Article published online in Administration \& Society 2020, https://doi.org/10.1177/0095399720957613 (this is the accepted version).

Authors: Sylke Jaspers and Trui Steen, KU Leuven, Public Governance Institute.

Corresponding author: Sylke.Jaspers@kuleuven.be

\title{
Does co-production lead to the creation of public value? Balancing the dimensions of public value creation in urban mobility planning
}

\begin{abstract}
Co-production is intended to co-create public value. This article analyses how coproducers address the tensions that arise among the various dimensions of public value. The paper builds on the theory of coping strategies to examine individuals' coping behaviours. Two urban mobility planning cases are studied in depth. This study finds that co-producers experience various tensions between public value dimensions. Furthermore, co-producers cope with the tensions both according to balancing strategies as well as trade-off strategies, preferring one value dimension over the other. Additionally, the empirical evidence provides examples of circumstances, such as communication, in which a balancing exercise is enhanced.
\end{abstract}

Keywords: co-production of public services, coping strategies, public value, co-creation of value, urban mobility planning

\section{Introduction}

Co-production, or the process of public servants and citizens collaborating in the provision of public services, is intended to lead to the co-creation of public value through "better use of each other's assets and resources" (Bovaird \& Loeffler, 2012, p. 121). Public value and public value creation are "concepts that focus on the appraisal of activities, actions, and outcomes produced by government agents and organizations" (Nabatchi, 2018, p. 60). When different 
actors unite to create public value, that public value is co-created (Moore, 1995; Bryson, Crosby \& Stone, 2015).

According to Bovaird and Loeffler (2012), value added to the public sector has several dimensions, each responding to different claims for public value creation: user value, value to wider groups, social value, environmental value and political value. Co-production is sometimes seen as a solution to the variety of claims that are made for public value creation, a variety that is experienced as a tension by public servants in regular service delivery (Jefferies, Bishop \& Hibbert, 2019). However, tensions around which value is to be created may persist when moving to collaborative practices, as co-producing actors have mixed motives that differ (Van Eijk \& Steen, 2014; Le Grand, 2003). Some tensions may fade out when co-production is introduced, yet other tensions may persist, and new tensions may arise (e.g., Needham \& Carr, 2009; Brandsen \& Helderman, 2012; Jaspers \& Steen, 2019).

Individuals use a variety of coping strategies to address the tensions that they experience. Some coping strategies may balance the tension by reconciling competing claims, while others may not; instead, for example, they may be biased in favour of one claim (Thacher \& Rein, 2004; Stewart, 2006). Different coping strategies may thus result in different outcomes for public value creation. In this paper, we aim to gain insight into the potential for the use of co-production for the creation of public value. We do so by analysing how public servants and citizen co-producers cope with the tensions among the different dimensions of public value. The conceptual lens of coping strategies helps us to achieve a better understanding of the intended and unintended consequences of the use of co-production for creating public value. The central question in this paper is the following: Does the use of co-production for creating public value cause participants to experience tensions among the dimensions of public value, and, if so, how do they cope with these tensions? 
The paper presents two cases, namely, 'City Streets' and 'Mobility Alternative', that involve citizens and public servants in the co-design and co-delivery of urban mobility plans. Since mobility and the use of public space encompass multiple claims for public service, these two cases provide an ideal setting in which to study the tensions that co-producers experience around public value creation and how they cope with these tensions.

This paper first discusses the concepts of co-production of public services, public value creation and coping strategies that constitute the analytical framework. Next, the two cases are presented, and the methods used for the empirical study are outlined. After that, the paper presents and discusses the results, focusing on the perceptions of both the citizen co-producers and the public servants involved. In the conclusion, we summarize the paper's contributions to the theory and the literature.

\section{Co-creating Public Value through Co-production}

\section{Definitions: Co-production and the Co-creation of Public Value}

In the process of co-production, services are not delivered for the people but with the people (Bovaird, 2007). Ostrom (1996) defines co-production as "the process through which inputs used to provide a good or service are contributed by individuals who are not in the same organization" (1996, p. 1073). These individuals may be clients or a group of citizens who collaborate with the “regular producer" (Ostrom, 1996). Brandsen and Honingh (2016) define co-production "as a relationship between a paid employee of an organization [i.e., a public servant] and (groups of) individual citizens that requires a direct and active contribution from these citizens to the work of the organization" (p. 431). Co-production may involve both the co-design and the coimplementation of a public service. Some scholars emphasize the distinction between the concepts of 'co-production' and 'co-creation'1 on the basis of the point in the policy cycle at which the coproduction is taking place (Brandsen and Honingh, 2018, p. 13). However, Bovaird and Loeffler 
(2012) suggest that when an initiative includes both the co-design and the co-delivery of a service, we use the term co-production for the overall process, which is the case for the situations discussed in this study.

Moore (1995) argues that "the aim of managerial work in the public sector is to create public value just as the aim of managerial work in the private sector is to create private value". It is important to distinguish between "public value" (e.g., Moore, 1995, 2014) and "public values" (e.g., Bozeman, 2007), as they each represent distinct concepts. The latter concept, namely, "public values", is not the focus of our paper, as public values are values that represent the "normative consensus about the rights [and obligations of citizens...] and the principles on which governments and policies should be based" (Bozeman, 2007, p. 13). The literature on public value creation is quite distinct from this concept, even if it refers to public values in many different ways. Public value and public value creation refer to the appraisal value of the activities of government agents and their outcomes (Nabatchi, 2018). The precise definition of public value, following Mark Moore's book on Creating Public Value, has been greatly debated in the public administration literature (e.g., Stoker, 2006; Rhodes \& Wanna, 2007). For this empirical study, we adhere to the definition of public value as added value created through the activities of public organizations and their managers. It includes the notions of added value and of what is considered to be valuable, "which is sometimes presented in terms of normative aspirations for a 'good society"” (Hartley et al., 2017, p. 672).

Co-production brings a specific context to public value creation wherein different actors co-create public value (Bryson et al., 2015). Ramirez (1999, p. 49) specifies that the good or the service that is co-produced is in essence "value coproduced by two or more actors, with and for each other, with and for yet other actors" (1999, p. 49). In traditional public service delivery, the public manager is understood to be the main creator of public value (Moore, 1995). However, in co- 
production, a variety of actors, including citizens, produce services and contribute to the value creation process (Bryson et al., 2015).

The idea of added value in the context of co-production is consistent with Bovaird and Loeffler's (2012, p.1126-1127) suggestion of the several dimensions of value added by the public sector:

- "user value

- value to wider groups (such as family or friends of service users, or individuals who are indirectly affected)

- social value (creation of social cohesion or support for social interaction)

- environmental value (ensuring environmental sustainability of all policies)

- political value (support to democratic process, e.g. through co-planning of services with users and other stakeholders)"

According to Bovaird and Loeffler (2012), it is likely that all of these elements are found to be important in the public sector, but the element of user value may be outweighed by the other dimensions. They argue that this is why an examination of the motivations of citizen co-producers is relevant. Service users may be motivated by their desire to ensure high levels of user value, environmentally conscious co-producers may be motivated to ensure the environmental sustainability of a service, and community-conscious co-producers may be focused on facilitating social inclusion and producing outcomes that benefit the "widest possible range of local community members" (p. 1127).

\section{Tensions in Creating Public Value}

Alford (2011) indicates that the user value, or private value, generated through co-production is intended for the individual, and that public value is intended for the citizenry; however, it is implied that co-producers may receive both. Nevertheless, the service producers engaged in coproduction may have different goals for the creation of public value, and these goals may conflict with one another (Brandsen \& Helderman, 2012; Osborne, Radnor \& Strokosch, 2016; Farr, 2016). There is extensive material in the co-production literature on the motivations underlying 
co-production (e.g., Van Eijk \& Steen, 2014). Van Eijk and Steen (2014) distinguish between selfcentred and community-centred motivations. Individual's motivations for co-production such as seeking self-development or feeling acknowledged by others, for example, are self-centred motivations. Alford and Yates (2016) point out that the activities of citizen co-producers are mostly (but not entirely) devoted to producing and maximizing their user value and ensuring high quality user value; for example, individuals receive the personal benefit of cost savings when sharing a car with a service of a local government. Clary et al. (1998) define community-centred motivations as normative (expressing humanitarian values) and altruistic motivations. Coproducers' aspirations may conflict with one another because each co-producer is often involved in co-production for mixed motivations, and these co-producers are not solely engaged out of selfinterest (Le Grand, 2003).

Additionally, research hints at persisting tensions among public servants between creating user value and creating other dimensions of public value when moving to collaborative practices (cf. Brudney \& England, 1983). Bovaird (2007) discusses the paradox that faces public servants: on the one hand, in co-production, "the professional has to be prepared to trust the decisions and behaviours of service users [...] rather than dictate them" (Bovaird, 2007, p. 856), while on the other hand, professionals cannot simply use the co-producers' opinions as an indication of the preferences of all the users of the delivered services (De Vries, 2002) or that of the citizenry at large. This illustrates the tension that exists between the user value of the individual co-producer, political value (to create legitimate support for policies through democratic processes), and social value (to serve the most citizens possible).

\section{Coping Strategies}

After gaining an understanding of the risks and opportunities posed by the tensions among the various dimensions of public value in the context of co-production, we use the concept of 
'coping' to analyse how such tensions are addressed ${ }^{2}$. Thacher and Rein (2004) develop a typology of coping strategies that offers guidance to managers who face value conflicts, resulting in three types of strategies. Building on their typology, Stewart (2006) identifies three more types of strategies.

First, individuals may apply coping strategies that include a trade-off approach. In such cases, the creation of one value hinders the creation of another value. This can include a bias strategy, where one value is preferred over the other (Stewart, 2006); a casuistry strategy, where individuals respond on the basis of previous experiences (Thacher \& Rein, 2004); or an incrementalism strategy, where individuals slowly and almost strategically increase their emphasis on one value at the expense of the other value (Stewart, 2006). Second, individuals may seek to balance the tension, for example, by implementing distinct policies that each support the creation of a specific value, which is called a hybridization strategy (Stewart, 2006); by using a firewall strategy, which involves appointing different institutions, units or positions to support each value (Thacher \& Rein, 2004); or by using a cycling strategy, which pays attention to each value sequentially (Thacher \& Rein, 2004).

Other studies identify additional coping strategies. An escalating strategy occurs when an individual escalates his or her questions about a tension existing between certain values to a higher administrative or legislative authority (Tetlock, 2000; de Graaf et al., 2016). An avoidance strategy occurs when an individual avoids dealing with the tension, which can, for example, take the form of deciding to postpone coping with the tension or dropping out of the co-production initiative (Lehoux, Daudelin \& Abelson, 2012; Jaspers and Steen, 2019).

How co-producers cope with these value tensions influences the outcome of the delivered service; some coping strategies may lead to the simultaneous creation of different dimensions of value, other strategies may lead to the creation of only one value dimension, and some 
strategies can endanger the creation of any value at all. Therefore, we present a model that groups coping strategies based on their likely result (Table 1).

\section{Table 1: Coping Strategies}

\begin{tabular}{l|ll}
\multicolumn{1}{l}{ Likely result } & Coping & Reference \\
\hline \multirow{2}{*}{1 value created } & Bias strategy & Stewart 2006 \\
\cline { 2 - 3 } & Casuistry & Thacher \& Rein 2004 \\
\cline { 2 - 3 } & Incrementalism & Stewart 2006 \\
& Hybridization & Stewart 2006 \\
\cline { 2 - 3 } & Cycling & Thacher \& Rein 2004 \\
\cline { 2 - 3 } lack of value co-creation by the & Building firewalls & Thacher \& Rein 2004 \\
& Escalating & Tetlock 2000, de Graaf, \\
& \multirow{2}{*}{ Avoidance: e.g. deferred } & Huberts \& Smulder 2016 \\
& coping & Lehoux, Daudelin \& Abelson \\
\end{tabular}

Studies show how the public servants engaged in the process of co-production adhere to the abovementioned coping strategies when experiencing value tensions. Citizen co-producers may apply the same range of strategies, but their methods of coping are often different from those of public servants (Aschhoff \& Vogel, 2018; Jaspers \& Steen, 2019).

In sum, in addition to the experienced tensions between the dimensions of public value creation, looking into the individual coping strategies co-producers adhere to allows us to gain insights into an individual mechanism of co-creating public value in the context of coproducing public services.

\section{Methodology}

An explorative design helps to gain insights into how co-producers cope with the tensions around creating public value. We operationalized public value as an added value desired by individuals, which, according to Hartley and others (2017), implies that public value should be empirically 
studied at the individual level. We adopted a qualitative approach because we aimed to gain insights into the expectations and experiences of individual co-producers. We studied two coproduction cases involving urban mobility planning that took place in two small cities in Flanders, North Belgium. Both of these cases addressed the design and implementation of a traffic circulation plan aimed at creating a more liveable city. We gave these cases the fictitious names of 'City Streets' and 'Mobility Alternative'. In the case of City Streets, the co-production employed resulted in the permanent implementation of the co-produced design; however, in the case of Mobility Alternative, the co-produced design was not implemented. Before further discussing the case selection, we first explain the specific context of urban mobility planning in relation to co-production.

\section{The cases}

\section{Urban mobility.}

Renewed city planning and mobility policies are often combined to address societal challenges such as a growing population and the liveability and safety of the city. However, redesigning mobility plans is not an easy task: a multiplicity of claims are made on the available public space, of which mobility is just one. Other claims include the use of the public space as a public domain, political space, liveable space and/or space for commerce (Agyeman \& Zavetovski, 2015; von Schönfeld \& Bertolini, 2016). Moreover, mobility in itself results in multiple claims; for example, car drivers, bus passengers, cyclists and pedestrians all have different and often conflicting needs. Participatory processes are often established to address these multiple needs, with the intention of balancing these needs and avoiding conflict (e.g., Bovaird, 2007; Watson, 2014). This makes the co-production of urban mobility planning an ideal setting in which to examine the tensions experienced among dimensions of public value and how such tensions are coped with. 
In Flanders, the municipalities are responsible for inviting direct participation in the areas as they see fit (Vlaamse Overheid, 2017). Additionally, mobility policy in Flanders is mandated by the municipalities, who hold far-reaching authority over the circulation of the traffic in their territory. The desire to redesign public spaces is common to many European cities, and the knowledge gained from these cases will be relevant not only for the academic literature but also for the practice and implementation of co-production.

\section{Case Selection.}

Co-production research often refers to best practices to identify the conditions that support the production of the desired outcomes of co-production. However, we follow the example set by Howlett (2012) and focus on a failed case (Mobility Alternative) in addition to a successfully implemented case (City Streets). This allows us to learn more about tensions and the role of coping strategies in the creation or destruction of public value. Studying a failed implementation allows us to better understand the factors that prevented the initiative from fully achieving its goal. We do not aim to study the "success" or "failure" of these cases; rather, we selected these cases to determine whether an analysis of certain tensions, as well as the coping strategies applied, is able to establish where the implementation of the project went wrong. Moreover, by selecting two different cases, we hope to analyse a wide range of tensions experienced and coping strategies used.

Additionally, the cases selected are consistent with the following characteristics: (1) they involve the co-production of a mobility service aimed at improving the sustainable mobility of the city; (2) they took place in the same year as the data collection, thus allowing the experiences to be fresh in the minds of the respondents; (3) they were characterized by the active involvement of citizens; and (4) they involved direct collaboration of citizens with public servants. 


\section{City Streets.}

City Streets is a citizen-organized co-production platform in a city of just over 100,000 inhabitants. Citizens organized themselves from the bottom up and designed a circulation plan for the city. Their aim was to improve the quality of life in the city by reducing the number of cars in the city centre. This citizen initiative worked with resources derived from supra-local subsidies as well as voluntary member contributions. The citizen platform of the City Streets project asked the local government to implement its proposed circulation plan. Although the local government did not agree with the platform's entire design, it was willing to co-design and co-implement parts of the design, as redesigning the mobility plan of the city was also on its agenda. Together, these organizations formed working groups responsible for communication, design, participation, and implementation, and each group held an equal number of public servants and citizens.

\section{Mobility Alternative.}

Mobility Alternative was initiated by a group of citizens answering a call for an urban mobility project that was made by a third-sector organization (TSO) that operates throughout Flanders. Local governments can apply for the guidance of this TSO in organizing a top-down coproduction process intended to create more environmentally sustainable mobility. However, Mobility Alternative was initiated by citizens who then invited the local government to codesign and co-produce a new mobility plan with them. This project occurred in a city of approximately 33,000 inhabitants. The local government agreed to facilitate three meetings and promised (by agreeing to participate) to experimentally co-deliver (implement) the finished codesigned project for one month. The citizens worked, together with one public servant and the alderman responsible for mobility, on the design of a new circulation plan for the city. The local government decided to only experimentally implement one aspect of the plan (making one street car free) for one day. 


\section{Respondents}

In total, 46 semi-structured in-depth interviews were conducted (see Table $2^{3}$ ). For the 'City Streets' project, we interviewed 31 people, and for the 'Mobility Alternative' project, we interviewed 15 people. The number of respondents reflects the extent of the participation in the project (since we interviewed almost half of all the participants) in each of the two initiatives. We divided the respondents into four groups: citizens, public servants, actors involved in a TSO, and politicians (see appendix A for the characteristics of the respondents).

Table 2: Snapshot of the respondents of the cases of City Streets and Mobility Alternative

\begin{tabular}{|c|c|c|c|c|c|c|c|c|c|c|c|}
\hline & \multicolumn{5}{|c|}{ City Streets } & \multicolumn{5}{|c|}{ Mobility Alternative } & Total \\
\hline & $\begin{array}{l}\# \\
\text { public } \\
\text { servant } \\
\text { s }\end{array}$ & $\begin{array}{l}\# \\
\text { citizen } \\
\text { s }\end{array}$ & $\begin{array}{l}\# \\
\text { TSO }\end{array}$ & $\begin{array}{l}\# \\
\text { Politicians }\end{array}$ & Total & $\begin{array}{l}\text { \#publi } \\
\text { c } \\
\text { servant } \\
\text { s }\end{array}$ & \#citizens & $\begin{array}{l}\text { \#TS } \\
\mathrm{O}\end{array}$ & $\begin{array}{l}\text { \#politician } \\
\mathrm{s}\end{array}$ & Total & \\
\hline $\begin{array}{l}\text { Respo } \\
\text { ndents }\end{array}$ & 8 & 16 & 5 & 2 & 31 & 1 & 10 & 3 & 1 & 15 & 46 \\
\hline Female & 3 & 4 & 3 & 1 & 11 & 0 & 7 & 1 & 1 & 9 & 20 \\
\hline Male & 5 & 12 & 2 & 1 & 20 & 1 & 3 & 2 & 0 & 6 & 26 \\
\hline
\end{tabular}

In the case of Mobility Alternative, we only interviewed one public servant. Due to the design of the co-production in that city, only one public servant was assigned to actively co-produce with the citizens. Although this design forms a bias as it limits the inferences that we can make on the basis of this one respondent's experiences, the inclusion of this case provided additional information on value tensions and when they might lead to the project failing to be implemented.

\section{Data Collection Method and Analysis}

We conducted semi-structured interviews since the aim of using a qualitative explorative method was to inductively identify a wide range of perspectives instead of being numerically representative. We asked the respondents about the motivations that led them to co-produce, their expectations of the co-production process, and their experiences around realizing these expectations. When tensions were explicitly mentioned by the respondents, we followed up by asking how they dealt with this situation. When tensions were not specifically mentioned but 
became clear from their reports, we followed up by asking if they experienced these issues as tensions. This is how we avoided interpretation bias and steering of the respondents' answers. A general topic list was designed, but the questions for each interview differed slightly, as they were adapted to the specific cases and actors' roles therein.

All interviews were recorded and transcribed while ensuring the respondents' anonymity. We analysed the expectations of the public servants and citizen co-producers, the tensions they experienced and their coping strategies. Additionally, to complement their perceptions, the actors from the TSOs and the aldermen were interviewed to obtain in-depth insight into the variety of the dynamics involved. A thorough and structural analysis of the interviews was carried out by using the software program NVivo (QSR NVivo 11). Codes were created based on the coping strategies theory and the public value literature. The final code list shown in Table 3 is the result of the literature review and the phases of open and axial coding. 
Table 3: Codes and sub-codes used for the interview analysis.

\begin{tabular}{l}
\hline \hline Desired value creation \\
Self-centered \\
user value \\
value to wider groups \\
Community-centered \\
value to wider community \\
social value \\
environmental value \\
political value \\
\hline \hline Coping strategies \\
Trade-Off \\
Bias \\
Incrementalism \\
Casuistry \\
Balancing \\
Hybridization \\
Building Firewalls \\
Cycling \\
No direct co-creation by the individual \\
Escalation \\
Avoidance \\
Deferred \\
\hline \hline Actor groups \\
Citizen co-producer \\
TSO employee \\
Politician \\
Public servant \\
\hline \hline
\end{tabular}

In this study, we illustrate the analysis with some of the specific examples found in the data of the two cases studied. By examining the individual perspectives of the participants, this paper first presents the results on the citizen co-producers' desires to create public value. Second, we analyse whether the citizens experienced tensions among different dimensions of public value and, if so, how they coped with these tensions. After that, we apply the same steps to the case of the public servants. 


\section{Results}

\section{Citizen Co-Producers' Desire to Create Value}

The respondents showed community-centred motivations to create social value, political value and environmental value. First, we observed a desire to create environmental value in the respondents' motivation to increase the sustainability of mobility and to create a more liveable city (CC2, CC3, CC5, CC6, CC7, CC12, CC19, CC21, CC24, CC25, T3, T4)4. For example, respondent CC2 state, "In the platform, there was a broad interest in how to make the city more liveable"5. In addition, respondent CC19 noted, "I see that the city is suffocating, and I am getting impatient waiting for a solution". By redesigning the urban mobility plan and banning cars from the city centre they thus wished to decrease the negative environmental impact of traffic on the quality of life in the city.

The results show that citizen co-producers look for support from the public for their newly designed mobility plan. In the case of City Streets the citizen co-producers did so by promoting the plan through a website and by placing interactive information boards on various squares in the city. Thereby the citizen co-producers also aimed to create political value, as they acknowledge the importance of legitimacy: "It was very important to create support in the city for the plan, because it was expected to bring some opposition, because mobility can be controversial" (CC14, also $\mathrm{CC} 3, \mathrm{CC} 5, \mathrm{CC} 10)$. In the case of Mobility Alternative, the citizen co-producers only realized the importance of large stakeholder support after the project: "We learned from it [the experience] that others should have been involved, other stakeholders; we were too like-minded, and that was an important learning experience" (CC20, also CC26).

The dimension of social value was also found to be an important aspect of value from the perspective of the respondents. The respondents mention a variety of aspects that may be linked with a desire to realize the social value dimension of public value such as ensuring participation 
with the neighbourhoods in the implementation phase $(\mathrm{CC} 3, \mathrm{CC} 5, \mathrm{CC} 10, \mathrm{CC} 12)$ and even strengthening civil society: "It is in the public interest to put [experimenting with citizens] on the map, not only because I am interested in it but also because I believe it strengthens society and that it is the ideal way to redesign city planning, so for me that is in the public interest" (CC12, also, $\mathrm{CC} 3, \mathrm{CC} 5, \mathrm{CC} 10, \mathrm{CC} 15)$. Some of the citizen co-producers even state they are specifically involved to ensure this social dimension of public value (CC5).

Additionally, self-centred motivations, or the creation of user value, played an important role in the participation of citizen co-producers. For example, in the case of City Streets, many of the citizen co-producers were experts with ties to businesses (e.g., consultancy) relating to urban planning, communication and participation, and they aimed to gain personal visibility and create

a network: "[being involved in City Streets] provides me with opportunities for jobs and assignments" (CC6, also CC1, CC2, CC3, CC10, CC12). In the case of Mobility Alternative, most of the co-producers were service users (e.g., they were cyclists in the city), and therefore it is not unexpected that the respondents are also looking to improve their user value by aiming to design and implement more bicycle lanes. As one respondent explicitly claimed, he wanted to improve the roads so that his needs will be met as a service user: "I am a cyclist, so that probably influences my choice" (CC21, also CC23).

\section{Tensions faced by Citizen Co-Producers and How Citizens Coped}

Some of the citizen co-producers expressed that, in their view, public value could be created at the same time as they created user value for themselves. An example: "If I find the actual design important, it's mostly in my own neighbourhood. But I am also involved, of course, for the broader vision and plan: the liveability of the city" $(\mathrm{CC} 2$, also $\mathrm{CC} 3, \mathrm{CC} 12, \mathrm{CC} 21)$. These respondents are thereby indicating that there is no inherent tension between creating user value and other 
dimensions of creating public value. Nevertheless, our data also revealed that respondents do experience tensions among the various dimensions of value creation.

User versus environmental value.

First, some citizen co-producers experienced a tension between their desired user value and other dimensions of public value. For example, one respondent of the City Streets project claimed that while co-designing the mobility plan, his desired user value conflicted with his desire to create environmental value $(\mathrm{CC} 4, \mathrm{CC} 15, \mathrm{CC} 18)$. When co-designing car-free zones (namely, areas without parking possibilities) of the street where he lives, he claimed that he was willing to prioritize the creation of public value over the creation of his own user value: "I am willing to give up personal interests, because I am responsible for co-creating the outcome of the project" (CC4). Other citizen co-producers who perceived that the desired user value of (other) individual users conflicted with the environmental value said that they preferred the creation of environmental value over individual user value: "If you decide on a direction for a street, you do not need to ask all the citizens of that street what direction the street should go in. Around that street, there are many more people getting value from the area, so that is much more important" (CC3, also CC5, CC10, CC14, CC18). While co-designing, some citizen co-producers also used a balancing strategy in order to create both user value for individual residents and environmental value for the wider community: “one particular street wanted even more [parking spots], so we suggested bike parking and maybe some small gardens on the street. They agreed, and that is the consensus now" (CC10).

In contrast, citizen co-producers who did not feel that their desired value was included in the co-production process became disappointed and demotivated. Distrust of the government even resulted in an avoidance strategy, causing some to drop out of the project: "I guess it also came from not trusting the city $100 \%$ and not having $100 \%$ confidence in the plan [...] I dropped out when I saw the tendency of politicians to use the efforts of citizens and say, 'Look what we are 
doing" (CC1, also CC5, CC26). By avoiding to deal with the tensions they are experiencing, citizen co-producers step away from co-creating any public value dimension. In doing so they are perhaps contributing to the destruction of certain dimensions of public value creation, such as for example, user value.

User values among different users.

In the cases of City Streets and Mobility Alternative, the citizen co-producers reported explicitly experiencing tensions among the various user values of different users: "The normal citizen just wants to park in front of the store" (CC18) and "Merchants want cars in front of their doors; I want a terrace in front of my door so when the weather is good, people can sit outside" (CC19, also $\mathrm{CC} 5)$. Some respondents again tried to balance these demands $(\mathrm{CC} 1, \mathrm{CC} 25)$ recognizing the need to take into account the value for users that oppose the urban mobility plan. One respondent even claimed that bringing together the value for these different users is what unites people and results in a plan that works for everybody (CC1). Others escalated this issue to the local government; these respondents believed that "a local government needs to make sure that the right information about mobility gets to the citizens" (CC18, also CC7). By escalating a tensions between various user values to the local government, they are distancing themselves from needing to cope with this tension.

Environmental versus political value.

In both of these cases, the citizen co-producers experienced a tension between the environmental value dimension of the project on the one hand and the political value dimension on the other. The results show how the respondents biased the creation of environmental value (the agreement for implementation of a new urban mobility plan) over the creation of political value. The latter was supposed to be ensured by the experimentation phase of the project which aimed at gaining legitimacy and support as it "helps with fading out the opposition" (CC5, also CC3, T3, CC23). 
For example, in the case of City Streets, some citizen co-producers preferred rapid co-design and decision-making to ensure the project's environmental value over creating support for the plan (political value): “On the one hand, our group needs to be very productive, and that means that not all people should be represented, because things have to go fast. On the other hand, not a lot of people know our platform, which may be counterproductive to our cause" (CC11, also CC12, $\mathrm{CC} 15, \mathrm{~T} 1, \mathrm{~T} 4)$. Nevertheless, citizen co-producers also expressed a desire to hybridize these two aspects: "We should [...] look for alternatives to include citizens" (CC8, also CC4, CC16, CC23).

Environmental versus social value.

In the case of City Streets, regarding the co-design of the plan, the citizens initially proposed a car-free zone in a low-income neighbourhood. However, the local government prioritized ensuring parking spaces for shopping and thus planned to build a large parking area. Most of the interviewed citizens experienced a tension between implementing the mobility plan and ensuring environmental value on the one hand and creating social value by actively protesting against the parking lot and ensuring public space for community activities on the other hand (CC3, $\mathrm{CC} 5$, $\mathrm{CC} 10, \mathrm{~T} 1)$. The citizens, however, mostly preferred the environmental value of the plan over its social value for this specific neighbourhood: "If we had clashed, then maybe the circulation plan would not have been designed and implemented. So, in that sense, it could have been dangerous for the citizen initiative" (CC6, also $\mathrm{CC} 3, \mathrm{CC} 5, \mathrm{CC} 10, \mathrm{CC} 11, \mathrm{CC} 14, \mathrm{CC} 15, \mathrm{~T} 3)$. In practice, they distanced themselves by claiming that the citizen platform had nothing to do with the plan for building the new large parking lot: "We wrote a letter that distanced us from the decision around the parking but promoted the rest of the plan, which was a strategic move to push the rest of the plan as far as possible" (CC5, also, CC10, CC14, CC15, T1). Other co-producers, who felt that they had less power to decide on these points of action, further avoided addressing the conflict by letting these other co-producers take the lead in coping with the tension (CC15, also CC26, T1). 
With regard to implementation of the City Streets project, an experimental period of one year was targeted, as this was expected to lead to a high rate of involvement among the community, thus creating communal social cohesion (social value). The social value of the co-implementation was reduced to a minimum. "There was a trade-off made between the experimentation period, and, with that, there was also a trade-off in the participation angle of the implementation of the plan. The experimentation period disappeared from the agreement. Well, the most important thing is to make the city accessible and sustainable" (CC3, also CC5, CC6, CC10, CC11, T1).

\section{Public Servants' Desire to Create Public Value}

Although most of the data presented in this section come from interviews with the public servants participating in the City Streets project, we also present the evidence from that of Mobility Alternative, as this respondent's motivations and expectations contribute to the explorative research. We found that public servants mostly referred to added political value and environmental value (due to the expertise present in the citizen platform) as reasons for implementing co-design and, to a lesser extent, to the user value generated by coimplementation.

In the case of City Streets, public servants were motivated by the environmental value that coproduction would add to the design of a new mobility plan because of the expertise present in the citizen platform: "[We are] giving space back to the citizens according to the function of a city, which means making it car-free and creating more space for pedestrians, bikers and green areas" (PP3, also PP8). The public servant involved in the Mobility Alternative project likewise expressed that including citizens in this process could lead to a better result: "I know that [co-production] can be enriching; it demands extra work, but it can lead to a better end result" (PP9). However, in the case of Mobility Alternative, the public servant stated that the 
sustainability policies that were prioritized are those concerning "water, because there are a lot of floods here, and energy" (PP9) rather than those concerning mobility.

The public servants in both cases expressed that citizen involvement in the design of a mobility plan ensures the dimension of political value by increasing its legitimacy: "[It] is really important to include citizens in the process; otherwise, you create a lack of support" (PP2, also PP1, PP3, PP6, PP8, PP9). The public servants in the case of City Streets found that when ensuring the political value of the mobility plan (including more citizens in order to create support for implementing the plan), they also needed to guard the creation of public value: "I think the decision is, in the end, the responsibility of the government because you are keeping an eye out for the public interest. Nevertheless, you do notice that involving citizens increases the support for a plan" (PP3, also PP5).

Additionally, concerning implementation, the respondents found that experimenting with citizens resulted in increased user value: "Participation, experimentation, and evaluation give you many insights on what works and what does not work and improve the quality of the permanent use of the square" (PP2, also PP3, PP6).

\section{Tensions that Public Servants Experienced Among the Dimensions of Public Value and Their Coping Strategies}

Although the data provided some examples where the public servants found that environmental value conflicted with political value or social value, most of the tensions that were experienced by the public servants were related to user value.

Environmental versus social value.

In the implementation phase of the City Streets project, public servants were encouraged by an alderman to gradually step away from the co-production process, as an alderman had experienced a tension between the creation of environmental value and social value: "We would have liked to work more experimentally, but the politicians wanted to make it qualitative and 
sustainable, because other cities showed us that non-qualitative materials may lead to the decay of the public domain. This conflicts" (PP4). They coped with this tension by building firewalls based on the city squares with which social value could still be created by the experimentation process: "There are squares and parks where you can really co-design together. It really depends on the conditions of the square" (PP6).

User value versus environmental value.

The public servants experienced a tension related to the multiple claims on the public domain. In the case of City Streets, a tension between creating user value for individual citizens and environmental value for the city resulted from the multiple claims on the public domain and from an excess of interests that needed to be taken into account. These tensions became apparent during the co-implementation of the newly designed plan for the City Streets project, during which the public servants would experiment together with the citizens to improve user value: "We have multiple claims on the public square, which, most of the time, offer great uses for the public square. But sometimes, one private claim can limit these possibilities. For example, the weekly market is strictly scheduled and organized. They need the whole square, which diminishes possibilities such as installing fountains, grass, etc." (PP2, also PP1, PP3, PP8). For this reason, the public servants limited the experimentation in some squares, which resembled an incrementalism strategy, and additionally on other squares adhered to a sudden bias prioritizing environmental value over user value, stopping the citizen involvement in designing the squares (PP2, PP8). Others escalated the decision to a higher level: "It is the college of aldermen that decides and approves" (PP1).

User value of co-producing citizens and the creation of public value.

During the co-design of mobility plans, the public servants experienced a tension between what they perceived to be user value for co-producing citizens and the creation of public value for wider groups. Both cases concerned citizen-initiated initiatives that included according to public 
servants, groups of like-minded people that represented a specific interest (PP4, PP6, PP9). The public servant involved in the Mobility Alternative project expressed, "Citizens look at things from [the perspective of] their own interests; they have affairs that they want to defend" (PP9, also P3). This public servant coped with the tension by dropping out of the project to focus on more urgent sustainability matters: "You try to balance what the highest needs in your community are; for us, that is water [...] and energy. And we choose to put our energy into those two areas" (PP9, also P3). The alderman stressed that the creation of public value is up to the government because "an individual only sees his or her sidewalk, [and] an interest group is very extreme in its reasoning and demands" ( $\mathrm{P} 3)$. For this reason, the alderman limited the implementation of the co-designed plan yet, by doing so, obstructed the creation of any added public value.

Similarly, in the case of City Streets, the public servants claimed that the citizens were concerned with their own user value and that they were not fully capable of transcending this desire to create user value: "I felt like they were highly motivated by their private interests and by trying to get public procurement for them. Which is very difficult because you need to stay neutral as a government representative" (PP4, also PP6). Nevertheless, the public servants involved in the City Streets project valued the citizens' involvement in public value creation. When coping with this tension, the public servants found that it was their role to guard the creation of public value (PP3, PP6, PP9). They balanced the user value of the citizen coproducers with the user value of the other stakeholders in society: "You need to give a voice to the citizens, and, although they are too focused on their personal needs, the challenge is to connect that to the stories of others" (PP6, also PP2, PP3, PP9). Some public servants coped in favour of the local government's vision, as they were accountable to the political level: "Sometimes, participation is not that welcomed when it is certain that there is a different vision" (PP1, also PP3). This view may also be interpreted as an escalation strategy where coping is escalated to the political level: "I don't have a problem because the college decided. 
So, the college has the power and they decide what happens and what does not" (PP7, also PP1).

User value of co-producing citizens versus political value.

The public servants experienced a tension between inviting citizens to co-produce to ensure user value and ensuring political value. They feared that the wider public would possibly not perceive the co-production and the citizens who participated to be legitimate because they were not representing the perceptions of the entire community: "I also found it very difficult to justify the co-production of the citizen platform to the outside world. It seems like an unelected power, and it was unclear on what basis of representation they got to co-produce" (PP5, also PP3, PP4, PP8).

In the City Streets project, during the co-design phase, public servants coped with this tension by scaling up efforts (a strategy of incrementalism): "We coped with this by fitting it into a vision of now (short-term), one that convinced people by providing alternatives" (PP3, also PP8). They organized information and feedback sessions to create support and encourage the involvement of the community. The public servants made claims about a lack of transparency or trust in the citizens' intentions, which minimalized the political value of the plan (PP1, PP3, PP4, PP8, PP9). However, some public servants said this trust was built by in-depth and transparent communication, which led them to believe that they were guaranteeing public value creation. This communication therefore enabled a hybridization strategy, eliminating the tension that was initially perceived between the user value of co-producers and political value. A specific example comes from the City Streets project: "Sometimes, you need to place yourself in the mentality of the citizen platform [...]. Especially in the beginning there was very little trust, and by talking, we got through it." (PP4, also PP1, PP9). In the case of Mobility Alternative, however, trust was absent at various levels. The alderman did not trust the citizens' intentions because they were not representative of the wider community; thus, the alderman 
did not believe in the political value of a co-produced mobility plan. A lack of trust seems to prompt the heavy use of a bias strategy for coping, preferring a specific viewpoint on political value over the environmental, social and user value that could potentially be added through coproduction and thereby destroying any value creation that comes from the collaboration taking place between citizens and the local government (P3). 
Table 4: Summary of the experienced tensions, followed coping strategies and their potential outcomes in City Streets (CS) and Mobility Alternative (MA)

\begin{tabular}{|c|c|c|c|c|}
\hline \multicolumn{5}{|c|}{ Citizen co-producers $(\mathrm{CC})$} \\
\hline \multicolumn{3}{|c|}{ Tensions } & Coping Strategies & Results \\
\hline \multirow[t]{5}{*}{ user value } & \multirow[t]{3}{*}{$\&$} & \multirow{3}{*}{$\begin{array}{l}\text { environmental } \\
\text { value } \\
\text { (D)† }\end{array}$} & bias & $\begin{array}{l}\text { creation of environmental value and potential } \\
\text { destruction of user value }\end{array}$ \\
\hline & & & balancing & creation of both value dimensions \\
\hline & & & avoidance & potential destruction of value dimension(s) \\
\hline & \multirow{2}{*}{\multicolumn{2}{|c|}{$\begin{array}{l}\& \quad \text { user value } \\
\text { (D) }\end{array}$}} & balancing & creation of various user values \\
\hline & & & escalating & leaving responsibility to public officials \\
\hline \multirow{4}{*}{$\begin{array}{l}\text { environmental } \\
\text { value }\end{array}$} & & political value & bias & destruction of political value \\
\hline & \multirow{3}{*}{\multicolumn{2}{|c|}{$\& \quad$ social value }} & bias & $\begin{array}{l}\text { destructing social value for a particular } \\
\text { neighbourhood }(\mathrm{CS}) \dagger \dagger\end{array}$ \\
\hline & & & avoidance & potential destruction of value dimension(s) \\
\hline & & & escalating & directing the responsibility to a steering group \\
\hline \multicolumn{5}{|c|}{ Public servants (PS) } \\
\hline \multicolumn{3}{|c|}{ Tensions } & Coping strategies & Results \\
\hline $\begin{array}{l}\text { environmental } \\
\text { value }\end{array}$ & & social value (I) & building firewalls & $\begin{array}{l}\text { installing squares with social value and other } \\
\text { squares with environmental value (CS) }\end{array}$ \\
\hline \multirow[t]{2}{*}{ user value } & \multirow{2}{*}{\multicolumn{2}{|c|}{$\begin{array}{ll}\& \quad \text { environmental } \\
\\
\text { value (I) }\end{array}$}} & incrementalism & $\begin{array}{l}\text { slowly prioritizing environmental value over user } \\
\text { value (CS) }\end{array}$ \\
\hline & & & escalating & $\begin{array}{l}\text { moving the responsibility of which value is } \\
\text { created to the college of mayor and aldermen. }\end{array}$ \\
\hline \multirow{6}{*}{$\begin{array}{l}\text { user value of } \\
\mathrm{CC}\end{array}$} & \multirow{3}{*}{\multicolumn{2}{|c|}{$\begin{array}{ll}\text { public value in } \\
\text { eyes of PS }\end{array}$}} & biasing public & no value co-creation through co-production (MA) \\
\hline & & & value & $\begin{array}{l}\text { guarding creation of public value by staying } \\
\text { involved (CS) }\end{array}$ \\
\hline & & & escalating & $\begin{array}{l}\text { moving the responsibility of coping to the college } \\
\text { of mayor and aldermen. }\end{array}$ \\
\hline & \multirow{3}{*}{\multicolumn{2}{|c|}{ \& political value }} & incrementalism & $\begin{array}{l}\text { putting more emphasis on creating political value } \\
\text { by scaling up efforts of creating support (CS) }\end{array}$ \\
\hline & & & hybridization & $\begin{array}{l}\text { facilitated by trust, public servants believed both } \\
\text { value dimensions to be created (CS) }\end{array}$ \\
\hline & & & avoidance & $\begin{array}{l}\text { value creation obstructed by a lack of trust, } \\
\text { avoiding implementation (MA) }\end{array}$ \\
\hline
\end{tabular}

\section{Discussion}

In this article, we analysed the interview data of 46 respondents in two cases of urban planning, a policy field where many (co-productive) activities are taking place and much value is cocreated. We found support for the assumption that citizen co-producers have mixed motives to 
co-produce, including both self-centred and community-centred motives (cf. Van Eijk \& Steen, 2014). In doing so, they aim for one or more of the dimensions of public value creation. Some of the respondents, motivated by self-centred motivations, coped according to avoidance and drop-out strategies when they were confronted with tensions between their user value and other value dimensions, such as environmental value or political value. This finding corroborates earlier research stating that shared interests should be consistent with individual self-interests for co-production to be successful on an individual level (Brandsen \& Helderman, 2012). Citizen co-producers, however, are also able to transcend their user value creation, balance this value with other dimensions of public value, or prefer the creation of environmental value. In the cases studied, the citizen co-producers added value by progressing and transforming the government's way of working, by getting issues on the agenda, and, in the case of City Streets, by providing the inputs (e.g., expertise) needed by the government.

However, public servants perceive citizens to be largely limited by their desire to create user value for themselves and often do not believe that citizen co-producers are representative of the larger community. According to their view, this limits the creation of political value. Even though public servants value co-production for its potential for creating political value, public servants are aware that a co-produced project involves like-minded people who represent specific views; therefore, these public servants experience difficulties in justifying collaboration with citizen co-producers to the wider community and the city council. Public servants see it as their role to guard the creation of public value by hybridizing the needs of various stakeholders, including not only those of citizen co-producers and non-co-producing citizens but also those stemming from the political level (e.g., re-election concerns). This strategy, however, in the opinion of the public servants, does not always lead to the best outcome. 
Our data corroborate some of the earlier findings regarding the constraints on collaboration, such as the challenge of attaining accountability and the inequality that persists in many collaborative practices. Nevertheless, our data indicate that co-production does hold several opportunities for adding value to the different public value dimensions. There are certain circumstances that either enhance or limit the public value creation of co-production. First, political will appears to be an important factor in this process. In the case of City Streets, political will was present in that the plan was implemented as part of an electoral programme. In the case of Mobility Alternative, political will was absent, as was trust in the citizen coproducers and a public servant who could facilitate citizen input. Second, due to the need for rapid progress, social value was the first dimension to be dropped in both cases. Third, in cases such as mobility for which expertise is necessary, citizen co-producers' expertise can be of great value. Additionally, the case of Mobility Alternative showed the limits of citizens' expertise and the need for public servants to ensure a design that takes into account the physical reality of the public domain and the needs and demands that come from other services necessary for creating public value. Finally, our data suggest that trust is an enhancing circumstance for the potential of co-production for public value co-creation. Where trust was absent, citizen co-producers and public servants used an avoidance or drop-out strategy. This is consistent with earlier findings that "even if formal service and outcome targets are met, a failure of trust will effectively destroy public value" (Kelly, Mulgan \& Muers, 2002, p. 17). Trust in the opposite party's intentions thus seems to be of essence, and communication may be used as a method to build this trust. We argue that the power of a public servant to create public value is conditional upon his/her willingness to allow him/herself to be driven by a citizen initiative and to guide the co-production process with knowledge, enthusiasm, administrative will, trust and a realistic approach. 


\section{Conclusion}

The qualitative case studies presented in this study offered the advantage of examining the tensions and coping strategies within the specific context of co-production. The design of the study, however, involved some limitations. First, although we studied two different cases in Flanders (Northern Belgium), the qualitative design of the study does not allow for generalization. The specific examples of expectations, value tensions and coping strategies presented in the results are not necessarily valid for other cases and contexts. Future research should focus on case studies within similar and different administrative systems to study the effect of the administrative context on the value tensions and coping behaviours of coproduction. Nevertheless, the case studies show the importance of value tensions in the creation of public value. It is not self-evident that co-production is a solution to public value tensions, as individuals' coping strategies may be decisive or co-decisive, regarding which dimension of public value is being overlooked or prioritized. Additionally, future research could examine other cases in which co-production was stopped or 'failed' to strengthen our conclusions regarding the role of (coping with) public value tensions for public value creation.

Our results have several implications for the literature on co-production and, more broadly, collaborative public management. This study shows the weight of motivations in collaborative projects and how inviting various stakeholders and citizens to collaborate may pose new challenges, especially for public managers, in that they must balance and take into account different expectations. In addition to public managers, other stakeholders also use coping strategies to address tensions. Moreover, we cannot claim that co-production balances the conflicting value dimensions of public value. A variety of actors introduce different interests. Our analysis shows that co-producing actors, because of their mixed and differing motives, experience a variety of tensions among the dimensions of public value. This paper used the theory of Bovaird and Loeffler (2012) to identify the various dimensions of public value. Our 
study shows that the classification of coping strategies is useful for studying the conflicts among public value dimensions. Additionally, the interactions among actors are an integral part of co-production. The comparison of the two cases in this study showed that it is precisely these interactions, taking the form of communication, that influence trust, which may result in the creation of added value by facilitating a balancing strategy. We therefore argue that, in addition to motivations and the effects of co-production, individual and collective behaviours are also important topics to consider in the co-production literature.

Our finding that a balancing strategy is facilitated by communication shows the importance of communication in the design of co-production. When a project begins, citizens, public servants and other actors should 'come clean' about their intentions and determine how these intentions can fit together. Practitioners should be aware that if these various expectations about value do not match, individual coping strategies may be used by themselves and others, and these strategies may affect (perhaps not deliberately) the outcome of the project and risk the destruction of its possible value. Future research should address the role of interaction and communication to complete the value co-creation theory and formulate recommendations for co-production design.

\section{Footnotes}

${ }^{1}$ In this sense, our central concept, namely, the "co-creation of public value", should not be confused with the concept of the "co-creation of public services", which Brandsen and Honingh (2018) explain as the process of "professionals and citizens co-designing public services".

${ }^{2}$ The literature identifies a variety of strategies for coping with the tensions among public values (plural, cf. Bozeman, 2007) (e.g., Tetlock, 2000; Thacher \& Rein, 2004; Stewart, 2006; de Graaf, Huberts \& Smulders, 2016). 
${ }^{3} \mathrm{~A}$ snapshot of the total number of participants was not possible for these cases since many people were involved at a different time, and the list of participants $(\mathrm{N}=50$ in the case of City Streets, and $\mathrm{N}=30$ - later reduced to 20 and finally to 10 - in the case of Mobility Alternative) did not seem to be fully accurate.

${ }^{4}$ The number identifies the respondent (see Appendix A for details on the respondents): $\mathrm{CC}=$ Citizen co-producer; $\mathrm{T}=$ employee of a $\mathrm{TSO} ; \mathrm{PP}=$ public professional, $\mathrm{P}=$ politician.

${ }^{5}$ The quotes presented in the results section were translated from Dutch by the first author.

\section{References}

Agyeman, J., \& Zavetovski, S. (2015). Incomplete streets: Processes, practices, and possibilities. Routledge.

Alford, J. (2011). Public value from co-production by clients. In: J. Benington \& M. H. Moore (2011), Public value: Theory and practice (pp. 144 - 157). Palgrave Macmillan.

Alford, J., \& Yates, S. (2016). Co-production of public services in Australia: The roles of government organisation and co-producers. Australian Journal of Public Administration, 75(2), 159-175. https://doi.org/10.1111/1467-8500.12157

Aschhoff, N. \& Vogel, R. (2018). Value conflicts in co-production: governing public values in multi-actor settings. International Journal of Public Sector Management, 33, 775-793. doi:10.1108/IJPSM-08-2017-0222

Bovaird, T. (2007). Beyond engagement and participation: User and community coproduction of public services. Public Administration Review, 67, 846-860. https://doi.org/10.1111/j.1540-6210.2007.00773.x 
Bovaird, T. \& Loeffler, E. (2012). From engagement to co-production: The contribution of users and communities to outcomes and public value. Voluntas. 23, 1119-1138. https://doi.org/10.1007/s1 1266-012-9309-6

Bozeman, B. (2007). Public values and public interest: counterbalancing economic individualism. Washington: Georgetown university press.

Brandsen, T., \& Helderman, J.-K. (2012). The trade-off between capital and community: The conditions for successful co-production in housing. International Journal of Voluntary and Nonprofit Organization, 23, 1139-1155. https://doi.org/10.1007/s11266-012-93100

Brandsen, T., \& Honingh, M. (2016). Distinguishing different types of coproduction: A conceptual analysis based on the classical definitions. Public Administration Review, 76(3), 427-435. https://doi.org/10.1111/puar.12465

Brandsen, T. \& Honingh, M. (2018). Definitions of co-production and co-creation. In T. Brandsen, T. Steen, \& B. Verschuere, B. (eds.), Coproduction and co-creation. Engaging citizens in public services (9-17). Routledge.

Brudney, J., \& England, R. (1983). Toward a definition of the coproduction concept. Public Adminsitration Review, 43(1), 59-65.

Bryson, J. M., Crosby, B. C., \& Stone, M. M. (2015). Designing and implementing cross-sector collaborations: Needed and Challenges. Public Administration Review, 75, 647-663. https://doi.org/10.1111/puar.12432

Clary, E., Ridge, R. D, Stukas, A. A., Snyder, M., Copeland, J., Haugen, J., \& Miene, P. (1998). Personality processes and individual differences. Journal of Personality and Social Psychology, 74, 1516-1530. DOI:10.1037/0022-3514.74.6.1516 
de Graaf, g., Huberts, L., \& Smulders, R. (2016). Coping with public value conflicts. Administration \& Society, 48, 1101-1127. https://doi.org/10.1177/0095399714532273

De Vries, M. (2002). Can you afford honesty? A comparative analysis of ethos and ethics in local government. Administration \& Society, 34, 309-334. http://dx.doi.org/10.1177/009539902400387218

Farr, M. (2016). Co-production and value co-creation in outcome-based contracting in public services. Public Management Review, 18, 654-672. https://doi.org/10.1080/14719037.2015.1111661

Hartley, J., Alford, J., Knies, E. \& Douglas, S. (2017). Towards an empirical research agenda for public value theory. Public Management Review, 19 (5), 670-685. https://doi.org/10.1080/14719037.2016.1192166

Howlett, M. (2012). The lessens of failure: learning and blame avoidance in public policymaking. International Political Science Review, 33(5), 539-555. https://doi.org/10.1177/0192512112453603.

Jefferies et al., Bishop, S., \& Hibbert, S. (2019). Service innovation through resource integration: An empirical examination of co-created value using telehealth services. Public Policy and Administration, Online first, https://doi.org/10.1177/0952076718822715

Jaspers, S., \& Steen, T. (2019). Realizing public values: enhancement or obstruction? Exploring value tensions and coping strategies in the co-production of social care. Public Management Review, 21(4), 607-627. https://doi.org/10.1080/14719037.2018.1508608 
Kelly, G., Mulgan, G., \& Muers, S. (2002). Creating public value: An analytical framework for public service delivery reform. Discussion paper prepared by the Cabinet Office Strategy Unit.

Le Grand, J. (2003). Motivation, Agency and Public Policy: Of Knights and Knaves, Pawns and Queens. Oxford: Oxford University Press.

Lehoux, Daudelin \& Abelson (2012). The unbearable lightness of citizens within public deliberation processes. Social Science \& Medicine, 74, 1843-1850. https://doi.org/10.1016/j.socscimed.2012.02.023

Moore, M. (1995). Creating public value: Strategic management in government. MA: Harvard University Press.

Moore, M. H. (2014). Public value accounting: Establishing the philosophical basis. Public Administration Review; 74, 465-477. https://doi.org/10.1111/puar.12198

Nabatchi, T. (2018). Public values frames in administration and governance. Perspectives on Public Management and Governance, 1, 59-72. https://doi.org/10.1093/ppmgov/gvx009

Needham, C., \& Carr, S. (2009). SCIE Research briefing 31: co-production: an emerging evidence base for adult social care transformation. London: Social Care Institute for Excellence. Retrieved from www.scie.org.uk

Osborne, S., Radnor, Z., \& Strokosch, K. (2016). Co-production and the co-creation of value in public services: A suitable case for treatment? Public Management Review, 18, 639653. https://doi.org/10.1080/14719037.2015.1111927

Ostrom, E. (1996). Crossing the great devide: coproduction, synergy, and development. World Development, 24, 1973-1087. https://doi.org/10.1.1.460.8258 
Ramirez, R. (1999). Value co-production: Intellectual origins and implications for practice and research. Strategic Management Journal, 20, 49-65. https://doi.org/10.1002/(SICI)1097-0266(199901)20:1<49::AID-SMJ20>3.0.CO;2-2

Rhodes, R.A.W. \& Wanna, J. (2007). The limits to public value, or rescuing responsible government from the platonic guardians. The Australian Journal of Public Administration, 66, 406-421. https://doi.org/10.1111/j.1467-8500.2007.00553.x

Stewart, J. (2006). Value conflict and policy change. Review of Policy Research, 23(1), 147152. https://doi.org/10.1111/j.1541-1338.2006.00192.x

Stoker, G. (2006), Public value management a new narrative for networked governance? American Review of Public Administration, 36(1), 41-57. https://doi.org/10.1177/0275074005282583

Tetlock, P. (2000). Coping with trade-offs: Psychological constraints and political implications.” In A. Lupia, M. McCubbins, and S. Popkin (eds.), Elements of reason. cognition, choice and the bounds of rationality. Cambridge University Press.

Thacher, D., \& Rein, R. (2004). Managing value conflict in public policy. Governance, 17(4), 457-486. https://doi.org/10.1111/j.0952-1895.2004.00254.x

Van Eijk, C., \& Steen, T. (2014). Why people co-produce: Analysing citizens' perceptions on co-planning engagement in health care services. Public Management Review, 16, 358-382. https://doi.org/10.1080/14719037.2013.841458

Vlaamse Overheid (2017, July). Witboek open en wendbare overheid. Departement Kanselarij en Bestuur, Brussel. Retrieved from: https://www.vlaanderen.be/publicaties/witboekopen-en-wendbare-overheid 
von Schönfeld, K., \& Bertolini, L. (2016). Urban Streets between public space and mobility. Transportation Research $\quad$ Procedia, $\quad$ 300-302. https://doi.org/10.1016/j.trpro.2016.12.089

Watson, V. (2014). Co-production and collaboration in planning - The difference. Planning Theory \& Practice, 15(1), 62-76. https://doi.org/10.1080/14649357.2013.866266 
Appendix A. Characteristics of the respondents

\begin{tabular}{|c|c|c|c|c|c|c|c|}
\hline $\mathbf{R}+$ & Case & Actor & $\mathbf{M} / \mathbf{F}$ & $\mathbf{R}$ & Case & Actor & $\mathbf{M} / \mathbf{F}$ \\
\hline $\mathrm{CC} 1$ & $\mathrm{CS}+$ & Citizen co-producer & $\mathrm{M}$ & PP3 & $\mathrm{CS}$ & Public professional & $\mathrm{F}$ \\
\hline $\mathrm{CC} 2$ & $\mathrm{CS}$ & Citizen co-producer & $\mathrm{M}$ & PP4 & $\mathrm{CS}$ & Public professional & $\mathrm{M}$ \\
\hline $\mathrm{CC} 3$ & $\mathrm{CS}$ & Citizen co-producer & $M$ & PP5 & $\mathrm{CS}$ & Public professional & $\mathrm{M}$ \\
\hline $\mathrm{CC} 4$ & $\mathrm{CS}$ & Citizen co-producer & $\mathrm{M}$ & PP6 & $\mathrm{CS}$ & Public professional & $\mathrm{F}$ \\
\hline $\mathrm{CC} 5$ & $\mathrm{CS}$ & Citizen co-producer & $\mathrm{F}$ & PP7 & $\mathrm{CS}$ & Public Professional & $\mathrm{M}$ \\
\hline CC6 & $\mathrm{CS}$ & Citizen co-producer & $\mathrm{M}$ & PP8 & $\mathrm{CS}$ & Public professional & M \\
\hline $\mathrm{CC} 7$ & $\mathrm{CS}$ & Citizen co-producer & $\mathrm{M}$ & P1 & $\mathrm{CS}$ & Politician & $\mathrm{M}$ \\
\hline $\mathrm{CC} 8$ & $\mathrm{CS}$ & Citizen co-producer & $\mathrm{F}$ & $\mathrm{P} 2$ & $\mathrm{CS}$ & Politician & $\mathrm{F}$ \\
\hline CC9 & $\mathrm{CS}$ & Citizen co-producer & $\mathrm{M}$ & $\begin{array}{l}\mathrm{CC} 1 \\
7\end{array}$ & $\begin{array}{l}\text { MA } \\
\dagger\end{array}$ & Citizen co-producer & $\mathrm{M}$ \\
\hline $\begin{array}{l}\mathrm{CC} 1 \\
0\end{array}$ & $\mathrm{CS}$ & Citizen co-producer & $\mathrm{M}$ & $\begin{array}{l}\mathrm{CC} 1 \\
8\end{array}$ & MA & $\begin{array}{l}\text { Citizen co-producer, } \\
\text { also politician }\end{array}$ & $\mathrm{M}$ \\
\hline $\begin{array}{l}\mathrm{CC} 1 \\
1\end{array}$ & $\mathrm{CS}$ & Citizen co-producer & $\mathrm{F}$ & $\begin{array}{l}\mathrm{CC} 1 \\
9\end{array}$ & MA & Citizen co-producer & $\mathrm{M}$ \\
\hline $\begin{array}{l}\mathrm{CC} 1 \\
2\end{array}$ & $\mathrm{CS}$ & Citizen co-producer & $\mathrm{M}$ & $\begin{array}{l}\mathrm{CC} 2 \\
0\end{array}$ & MA & Citizen co-producer & $\mathrm{M}$ \\
\hline $\begin{array}{l}\mathrm{CC} 1 \\
3\end{array}$ & $\mathrm{CS}$ & Citizen co-producer & $\bar{F}$ & $\begin{array}{l}\mathrm{CC} 2 \\
1\end{array}$ & MA & Citizen co-producer & $\mathrm{M}$ \\
\hline $\begin{array}{l}\mathrm{CC} 1 \\
4\end{array}$ & $\mathrm{CS}$ & Citizen co-producer & $\mathrm{M}$ & $\begin{array}{l}\mathrm{CC} 2 \\
2\end{array}$ & MA & Citizen co-producer & $\mathrm{F}$ \\
\hline $\begin{array}{l}\mathrm{CC} 1 \\
5\end{array}$ & $\mathrm{CS}$ & Citizen co-producer & $\mathrm{M}$ & $\begin{array}{l}\mathrm{CC} 2 \\
3\end{array}$ & MA & Citizen co-producer & $\mathrm{F}$ \\
\hline $\begin{array}{l}\mathrm{CC} 1 \\
6\end{array}$ & $\mathrm{CS}$ & $\begin{array}{l}\text { Citizen co-producer, } \\
\text { also public } \\
\text { professional }\end{array}$ & $\mathrm{M}$ & $\begin{array}{l}\mathrm{CC} 2 \\
4\end{array}$ & MA & Citizen co-producer & $\bar{F}$ \\
\hline $\mathrm{T} 1$ & $\mathrm{CS}$ & TSO & $\bar{F}$ & $\begin{array}{l}\mathrm{CC} 2 \\
5\end{array}$ & MA & Citizen co-producer & $\mathrm{M}$ \\
\hline $\mathrm{T} 2$ & $\mathrm{CS}$ & TSO & $\mathrm{M}$ & $\begin{array}{l}\mathrm{CC} 2 \\
6\end{array}$ & MA & Citizen co-producer & $\mathrm{M}$ \\
\hline $\mathrm{T} 3$ & $\mathrm{CS}$ & TSO & $\mathrm{F}$ & T6 & MA & TSO & $\mathrm{F}$ \\
\hline $\mathrm{T} 4$ & $\mathrm{CS}$ & TSO & $\mathrm{M}$ & $\mathrm{T} 7$ & MA & TSO & $\mathrm{F}$ \\
\hline $\mathrm{T} 5$ & $\mathrm{CS}$ & TSO & $\mathrm{F}$ & T8 & MA & TSO & $\mathrm{M}$ \\
\hline PP1 & $\mathrm{CS}$ & Public professional & $\mathrm{F}$ & PP9 & MA & Public professional & $\mathrm{F}$ \\
\hline PP2 & $\mathrm{CS}$ & Public professional & $\mathrm{M}$ & P3 & MA & Politician & $\mathrm{M}$ \\
\hline
\end{tabular}

† $\mathrm{R}=$ Respondent, $\mathrm{SC}=$ City Streets, $\mathrm{MA}=$ Mobility Alternative 